\title{
The Macroeconomic Consequences of Disasters
}

\author{
by Ilan Noy,* \\ Department of Economics, University of Hawaii at Manoa
}

Working Paper No. 07-7

February 2007

\begin{abstract}
The aim of this study is to describe the macroeconomic dynamics of natural disasters and their determinants in a large sample of disaster events, the first such attempt we are aware of. Our research shows that natural disasters have a statistically observable adverse impact on the macroeconomy in the short-run. Not surprisingly, costlier events cause more pronounced slowdowns in production. Yet, interestingly, developing countries, and smaller economies, face much larger output declines following a disaster of similar relative magnitude than do developed countries or bigger economies. A close study of the determinants of these adverse macroeconomic output costs reveals several interesting patterns. Countries with a higher literacy rate, better institutions, higher per capita income, higher degree of openness to trade, and higher levels of government spending are better able to withstand the initial disaster shock and prevent further spillovers into the macroeconomy. These all suggest an increased ability to mobilize resources for reconstruction. Financial conditions also seem to be of importance; countries with more foreign exchange reserves, and higher levels of domestic credit, but with less-open capital accounts appear more robust and better able to endure natural disasters, with less adverse spillover into domestic production.
\end{abstract}

Key Words: Natural disasters, growth.

JEL Codes: 040, Q54

\footnotetext{
* I thank Jackie Lindo and Noi Nualsri for help with data collection, Menzie Chinn, Sebastian Edwards, Adam Honig and Hiro Ito for sharing their data, and Tim Halliday, Joe Joyce, Sally Kwak, Nori Tarui and seminar participants at UHM for useful comments. Address: 2424 Maile Way; Honolulu, HI 96822. Email: noy@hawaii.edu. All errors are my own.
} 


\section{Introduction}

Natural disasters have resulted in significant economic and human loss for millennia. Major recent catastrophic events — such as the December 2004 tsunami disaster in the Indian Ocean, the Pakistani Kashmir earthquake of October 2005 and the September 2005 inundation of New Orleans following hurricane Katrina — have brought the human and material cost of these crises to the forefront of public attention worldwide.

Natural disasters also figure prominently in discussions on future preparedness, especially in relation to the evident warming of the planet and the attendant changes in the patterns of climatic events that are predicted to accompany such warming (IPCC, 2007). ${ }^{1}$ The United Nations, for example, reports that: "Since 2000, some 1.6 billion have lost their homes or livelihoods or have suffered other damage [as a result of a natural disaster - IN]. This continues an upward trend over the past several decades and represents a four-fold annual increase, on average, from the decade of the 1970s.” (Schwartz, 2006).

The United Nation's Integrated Regional Information Network notes, "while the number of lives lost has declined in the past 20 years - 800,000 people died from natural disasters in the 1990s, compared with 2 million in the 1970s — the number of people affected has risen. Over the past decade, the total affected by natural disasters has tripled to 2 billion.” (IRIN, 2005). Therefore, much research in both the social and natural sciences has been devoted to increasing our ability to predict disasters, prepare for them and mitigate their costs. ${ }^{2}$ Curiously, few economists participate in developing this research agenda, and not many attempt to answer the many economically relevant

\footnotetext{
${ }^{1}$ Increasing levels of greenhouse gases, changing sea, land and air temperatures, rising sea levels, changing patterns of rain and snow and an unstable climate are all likely catalysts of future events.

${ }^{2}$ Much of this effort can be accessed through: http://www.colorado.edu/hazards/
} 
questions relating to natural disasters.

Almost all the current research on the topic focuses on disasters ex ante, as is done in the large preparedness literature that aims to describe how societies should better prepare themselves to the onset of disasters and reduce the direct damage they cause. In contrast, we focus on the natural disasters' ex post impact on the macroeconomy. We measure and estimate the costs of these crises in terms of forgone production, and using a comprehensive international macroeconomic panel dataset, we critically examine several hypotheses regarding the determinants of these costs. Given the importance of the problem, it is somewhat surprising that this has not been done before. Our effort enables us to compare the incidence and costs of disasters across geographical areas and income levels and provide answers to several hypotheses regarding structural and policy-related aspects of these costs.

In the next section, we discuss the existing economic literature and highlight our contribution to it. In the following sections we discuss the data, methodology, and findings of this paper. We conclude by pointing out some policy implications of our findings, and put forth a future research agenda on this topic.

2. The economics of natural disasters

Economic research on natural disasters is only in its infancy with very few papers examining any facet of disaster phenomena. Two exceptions of well developed research strands are worth noting. There is a significant body of micro-development research which examines the ways in which (especially rural) households prepare and deal with sudden unexpected income shocks (such as draughts) and their ability to insure against 
these shocks (e.g., Townsend, 1994; Paxson, 1989; and Udry, 1994). The second existing strand examines specific case studies - disaster events - such as the devastating hurricane Mitch in Honduras, and estimates some of the specific costs and consequences of those individual events (e.g., Benson and Clay, 2004; Halliday, 2006; Holtz-Eakin, 2005; Horwich, 2000; Narayan, 2001; Selcuk and Yeldan, 2001; and Vos et al., 1999).

The first strand is indirectly related to our investigation as it suggests that institutional characteristics and policy choices may have an impact on the macroeconomic consequences by shaping the individual households' decisions following disasters. The second strand is more directly relevant as a source for our hypotheses. The difficulty in judging the general applicability of the findings reported in these case studies, however, is part of the justification for our comparative work. Our findings may provide indication of any general conclusions that otherwise can only be derived with a meta-analysis relying on a large number of such case studies.

As far as we know, there are only very few papers that examine any macroeconomic facet of natural disasters using a multi-country, multi-event framework. These are briefly discussed below, though none of them attempts to answer the questions we pursue hereafter. The first recent attempt to empirically describe macro-aspects of natural disasters is Albala-Bertrand (1993). In this seminal monograph, Albala-Bertrand develops an analytical model of disaster occurrence and reaction and collects data on a set of disaster events: 28 disasters in 26 countries during 1960-1979. Based on beforeafter statistical analysis, he finds that GDP increases, inflation does not change, capital formation increases, agricultural and construction output increase, the twin deficits increase (the trade deficit sharply), reserves increase, but no discernible impact on the 
exchange rate is observed. The patterns of onset and recovery observable in this dataset are then described with a special emphasis on the political economy aspects of the events themselves. Rasmussen (2004) conducts a similar tabulation of the data for Caribbean Islands.

Skidmore and Toya (2002) examine the long-run impact of natural disasters on growth. They count the frequency of natural disasters for the 1960-1990 period for each country (normalized by land size) and pursue an empirical investigation of the correlation of this measure to average measures of economic growth, physical and human capital accumulation and total factor productivity for this 30 years period. Skidmore and Toya's (2002) paper investigates long-run trends (averages) in contrast with our aim of describing the short-run dynamics of the macroeconomy following disasters. Long-run analysis raises questions of endogeneity in disaster impact that are, to a large extent, not relevant for the short-run. ${ }^{3}$ Furthermore, their use of a cross section is conceptually and empirically very different from our reliance on a panel framework.

In the paper closest to ours in its interest, Raddatz (2007) investigates the external sources of output volatility in low income developing countries. Using a VAR approach, the paper analyses the contribution of various external shocks, natural disasters among them, in explaining output fluctuations. For our purposes, Raddatz's (2007) finding that natural disasters do have an adverse short-run impact on output dynamics is of interest. ${ }^{4}$ Raddatz’s (2007) focus on several types of external shocks, and its VAR approach,

\footnotetext{
${ }^{3}$ Skidmore and Toya's (2002) work utilizes the frequency of disasters; yet it important to note that only those disasters that resulted in significant damages get registered in the EM-DAT (see section 3). The issue is highlighted by the finding of another strand that identifies per capita income as a significant determinant of the direct costs of natural disasters (see Kahn, 2004; and Skidmore and Toya, 2007).

${ }^{4}$ Yet, Raddatz (2007) concludes that only a small fraction of the output volatility in a typical low income country is explained by external advrse shocks (which include disasters).
} 
preclude it from answering the various questions posed here with respect to the determinants of the observed output declines following disasters.

\section{Data}

The data on natural disasters and their human impact are documented in the EMDAT database with data collected by the Centre for Research on the Epidemiology of Disasters (CRED). ${ }^{5}$ The EM-DAT database has worldwide coverage, and contains data on the occurrence and effects of natural disasters from 1900 to the present. The database is compiled from various sources, including UN agencies, non-governmental organizations, insurance companies, research institutions and press agencies. The EMDAT data is publicly available on CRED's web site at: www.cred.be.

CRED defines a disaster as a natural situation or event which overwhelms local capacity, necessitating a request for external assistance. For a disaster to be entered into the EM-DAT database at least one of the following criteria must be fulfilled: (1) 10 or more people reported killed; (2) 100 people reported affected; (3) declaration of a state of emergency; or (4) call for international assistance. ${ }^{6}$ These disasters can be hydrometeorological disasters including floods, wave surges, storms, droughts, landslides and avalanches; geophysical disasters - earthquakes, tsunamis and volcanic eruptions; and biological disasters covering epidemics and insect infestations (these are much more infrequent).

\footnotetext{
${ }^{5}$ Established in 1973 as a non-profit institution, CRED is based at the Catholic University of Louvain in Belgium.

${ }^{6}$ The number of people killed includes "persons confirmed as dead and persons missing and presumed dead"; people affected are those "requiring immediate assistance during a period of emergency, i.e. requiring basic survival needs such as food, water, shelter, sanitation and immediate medical assistance.”
} 
The amount of damage reported in the database consists only of direct damages (e.g. damage to infrastructure, crops, housing) and do not include the indirect or secondary damages - an attempt to estimate these secondary effects is, in part, our aim here. We utilize three reported measures of the magnitude of the disaster: (1) The number of people killed (DKIL); (2) the number of people affected (DAFF); and (3) the amount of direct damage (DDAM). For the years 1970-2003, we have data on the number of people killed for 507 disaster events, the number of people affected for 466 events, and the amount of damage in 428 events.

Since we presume that the impact of a specific natural disaster on the macroeconomy depends on the magnitude of the disaster relative to the size of the economy, we standardize our disaster measures. We divide the measures for the number of people killed or affected by the population size in the year prior to the disaster year; and divide the direct cost measure of the disaster by the last year’s GDP (since the current year's population and GDP have been affected by the disaster itself). Furthermore, since it is likely that a disaster that occurred in January of 1995 will have a bigger impact on the macro-economy in the same year than a disaster that occurred in December, we weigh our measure based on the month in which the disaster occurred (or began). Specifically, the disaster measures ( DMS ) we employ in our specifications are calculated based on the cost measure ( $D M)$ and the onset month $(O M)$ :

$D M S=D M(12-O M) / 12$

From the outset, it should be clear that doubts have been expressed about the accuracy of data on natural disasters; especially because often the major source of these data (national governments) has an interest in inflating the measured impact. Yet, since 
biases should by systemic, using data from one source should provide information about the relative magnitude of disasters and should thus be appropriate for the hypotheses we examine here. $^{7}$

Data on GDP growth, per capita income levels, CPI inflation, unemployment rate and population, as well as the other macroeconomic control variables, comes primarily from the World Bank’s World Development Indicators. Because of data availability constraints, our panel covers the years 1970-2003. Exact detailed are provided in the data appendix.

The data on natural disasters is described in tables 1 and 2. In table 1 , we provide the main statistical characteristics of the 3 measures of interest; the mean, standard deviation, minimum, and maximum. In table 2, we divide our sample by income level and regional location and describe the means, medians, and number of observations we have for each region. From this table, we note that disasters apparently are significantly more costly for developing countries than they are for developed ones. ${ }^{8}$ Disasters in South-, South-East, and East Asia are also more costly (in both human life and property damage) than those occurring in the Middle East, and Latin America. This might be at least partly a result of the higher population density in Asia. More striking is the difference between island-states and all other geographical regions. Islands are apparently very vulnerable to disasters, with costs to life, the number of people affected, and the property damage incurred all are, on average, twice as large as in any other region.

\footnotetext{
${ }^{7}$ Furthermore, if stated damages are indeed biased upward, than the size of the estimated coefficients is biased downward (see Hausman, 2001, for more details).

${ }^{8}$ At least some of this difference, though, can plausibly be accounted for by a selection bias due to different reporting practices. It is likely that for developed countries, smaller disasters (in terms of costs to life or property) will also be reported to CRED.
} 
4. Methodology and results

Our main aim in this paper is to describe the macro-economic consequences of natural disasters. In particular, we estimate the indirect costs to output - the reduction in GDP growth - the typically result from a natural disaster. We start by examining the most parsimonious specification:

$y_{i, t}=\alpha_{i}+\beta y_{i, t-1}+\gamma D M S_{i, t}+\phi X_{i, \square}+\varepsilon_{i t}$

where $y_{i, t}$ is the GDP growth rate, $D M S_{i, t}$ is our measure for disaster magnitude, and $X_{i, \square}$ are control variables commonly used in the growth literature. Following Islam (1995) and most subsequent research on short-run GDP growth empirical models, we add to the specification a GDP growth lag $\left(y_{i, t-1}\right) .{ }^{9}$ Country-specific effects are introduced in order to account for the widely varying average growth experiences among different countries over the past two decades. This setup explicitly removes the cross-sectional long-run differences which were the focus of Skidmore and Toya (2002).

In our estimates we follow a procedure first suggested by Hausman and Taylor (1981) that takes into account the bias in estimation of panels with predetermined and/or endogenous variables. For a rigorous formulation of this bias see Nickel (1981). The Hausman-Taylor three-step estimation methodology is an instrumental variable estimator that takes into account the possible correlation between the disturbance term and the variables specified as predetermined/endogenous. The estimated equation is thus:

$$
y_{i, t}=\alpha_{i}+\beta y_{i, t-1}+\gamma D M S_{i, t}+\phi^{1} X_{i, \square}^{1}+\phi^{2} X_{i, \square}^{2}+\varepsilon_{i t}
$$

\footnotetext{
${ }^{9}$ The use of only one lag is supported by recent research (e.g., Uribe and Yue, 2006, and Raddatz, 2007).
} 
where $X_{i, \square}^{1}$ are the control variables assumed to be (weakly) exogenous and $X_{i, \square}^{2}$ are assumed to be predetermined/endogenous and thus correlated with the country specific term. $^{10}$

In the first step, least squares estimates (from a country fixed-effects model) are employed to obtain consistent but inefficient estimates for the variance components for the coefficients of the time-varying variables. In the second step, an FGLS procedure is employed to obtain variances for the time-invariant variables. The third step is a weighted IV estimation using deviation from means of lagged values of the time-varying variables as instruments. Identification in the Hausman-Taylor procedure requires that the number of exogenous variables be at least as large as the number of time-invariant predetermined/endogenous variables. The exogeneity assumption requires that the means of the exogenous variables $\left(\bar{X}_{i}^{1}\right)$ will be uncorrelated with the country effects $\left(\alpha_{i}\right){ }^{11,12}$

The Hausman-Taylor methodology is intended to overcome the possible correlation between the country specific effects and the independent variables in a dynamic panel set-up. Yet, in order to argue for the causal effect of the disaster variables

\footnotetext{
${ }^{10}$ Given the construction of our disaster variable as ratio of pervious year's domestic product, this variable is clearly predetermined. We do note that classifying the disaster variable as exogenous does not change any of the results we report (when it is classified as predetermined/endogenous).

${ }^{11} p \lim _{N \rightarrow \infty}\left(\left[\sum_{i=1}^{N} \alpha_{i} X_{i}^{1}\right] / N\right)=0$

${ }^{12}$ Under the plausible exogeneity assumption described above, the Hausman-Taylor (HT) procedure provides asymptotically consistent estimates, but it is not the most efficient estimator possible. For a dynamic panel set-up, more efficient GMM procedures rely on utilizing more available moment conditions to obtain a more efficient estimation (e.g., Arellano and Bond, 1991). This procedure, however, is usually employed in estimation of panels with a large number of individuals and short time-series and in our case, the number of instruments used will be very large (and the system will be vastly over-identified); see Baltagi (2005). Furthermore, the data makes this procedure difficult to implement for most specifications of the model; see Greene (2002) on the practical difficulty in implementing AB-GMM. Hutchison and Noy (2005) compare these methodologies and show that using the Arellano and Bond (1991) GMM framework in similar growth specifications the coefficients do not change noticeably when compared to the Hausman and Taylor (1981) estimates, though their statistical significance increases as predicted.
} 
on our macroeconomic measures of interest (mainly GDP growth), we require further assumptions. We see no a priori reason to argue that these disaster measures will face any reverse causality from the GDP growth variable (i.e., GDP growth will Granger cause future disasters); we thus assume full exogeneity of these measures. This assumption is also adopted by the two other papers that use a disaster measure as an independent variable, albeit in different specifications (Raddatz, 2007 and Skidmore and Toya, 2002). To verify that the way we construct the disaster measure using lagged GDP levels (see eq. 1) does not insert any endogeneity into our measure we also run the same specifications using a binary indicator of disaster occurrence and find the qualitative results identical. A further informal test of the exogeneity assumption is to compare the distribution of the independent variables for the disaster and no-disaster observations. We find no statistically observable difference in their means.

Preliminary results presented in table 3, without the control variables, point to two general conclusions. There is no evidence of any correlation between the disaster population variables (number killed or affected) and GDP growth (table 3 columns 2 \& 3). However, we obtain strong indication that the amount of property damage incurred during the disaster is a negative determinant of GDP growth performance; and also find that larger disasters, or those that happen earlier in the year, have a more adverse affect (table 3 column 1). ${ }^{13}$

To further investigate whether there are any reasons to suspect the way we constructed the damage variables created any endogeneity problem, we convert the disaster measures we have into binary indicators ( $1=$ disaster, $0=$ no disaster) to examine

\footnotetext{
${ }^{13}$ This might be construed as hardly surprising, and is in line with the Raddartz (2007) conclusion. But, it is distinct from the conclusions presented in Skidmore and Toya, (2002) in their research on the long-run effect of disasters, and is also in contrast with some of the descriptive case studies (e.g., Horwich, 2000).
} 
whether this changes our results. ${ }^{14}$ Again, we find a significant coefficient for the damage variable in these specifications (table 3 columns 4-6).

Next, we examine specifications that also include other control variables commonly found in the empirical growth literature. The additional determinants of output in this model are a set of domestic policy, structural, and external factors, as well as country-specific effects and the lagged output growth already included in the specifications presented in table 3. The domestic policy factors are changes in government budget surpluses, inflation, investment, and credit growth. External factors include the current account and foreign direct investment inflows; and the structural factors we consider are the openness of the economy to international trade (import ratio), a measure of institutional quality and a binary measure for financial crises. ${ }^{15}$ All of the variables, with the exception of financial/capital-flows-stop crisis measure, are introduced with a one-year lag in order to capture the delayed response of output to macroeconomic developments. Exact details on measurements and sources are included in a data appendix.

Since our preliminary investigation in table 3 only yielded significant results for the property damage measure of crises, we focus only on this measure in all the following specifications. In our benchmark specification (table 4 column 1), we include the disaster measure and the other variables previously described. For the control variables, better institutions, lower credit growth, a higher current account surplus, larger FDI inflows and the absence of a financial crisis are all significantly associated with higher GDP growth.

\footnotetext{
${ }^{14}$ Because the binary approach masks the distinctions between the magnitudes of different disasters, we only record (binary variable $=1$ ) those disasters whose magnitude is bigger than the mean for that type of disaster data.

${ }^{15}$ For a discussion of sudden capital inflow stops (financial crises), and their empirical importance in growth dynamics, see Hutchison and Noy (2006).
} 
Past investment growth, the government deficit, the inflation rate, or imports do not seem to have a discernible impact on output performance in our specifications. We note that since the disaster measures are most likely strongly exogenous, we anyway do not expect their estimated coefficients to be affected by the inclusion of these controls (compare table 4 column 1 to table 3 column 1 ).

In columns 2 and 3 of table 4, we split our sample into developed countries (defined as 1990 members of the OECD) and developing countries (the rest). The obvious conclusion is that the negative impact of natural disasters on the macroeconomy is entirely due to output dynamics in the developing countries sample. This description does not apply to developed countries. One possible reason is the amply documented ability of developed countries to pursue counter-cyclical fiscal and monetary policy following adverse shocks - an ability that does not seem to be enjoyed by lower income countries who often end up pursuing pro-cyclical policies in the face of external shocks.

We further investigate whether big economies are more or less vulnerable to the impact of natural disasters. We now split the sample by the median size of the economy (measured in constant US\$). We find, maybe not surprisingly, that small economies are more vulnerable to an event of the same size (relative to their size). This may be due to the fact that smaller economies are less diversified, and their ability to withstand external shocks, especially to their agricultural sector, is thus diminished. We investigate these issues further in the next tables.

The economic importance of these statistically identifiable effects is very real. A one standard deviation increase in the direct damages of a natural disaster in a developing country will reduce output growth by about $9 \%$. We obtain similar magnitudes for small 
economies. The effect on developed countries is statistically significant but the economic importance is only marginal with the observed increase lower than $1 \%$.

In further specifications, we aim to answer several questions regarding the determinants of the output declines identified in the previous tables. Specifically, we would like to examine whether institutional and structural aspects of the $\left(Z_{i, t}\right)$ of the economies struck by disasters have any bearing on the magnitude of output decline that typically follows. We thus estimate the following specification:

$y_{i, t}=\alpha_{i}+\beta y_{i, t-1}+\gamma D M S_{i, t}+\delta\left(D M S_{i, t} \cdot Z_{i, t}\right)+\tau Z_{i, t}+\phi X_{i, t-1}+\varepsilon_{i t}$

The coefficient on the interaction of the natural disaster measure and the institutional/structural macroeconomic variable $(\delta)$ will define the effect of these characteristics on the magnitude of the output loss. ${ }^{16}$

We describe our hypotheses and the results concerning structural/real characteristics of the economy in table 5 and financial characteristics in table 6 . We first examine whether the level of human capital affects the impact of a financial crisis. It is likely that in economies in which the level of human capital is higher, the impact of loss of physical capital on the macroeconomy will be lower. We confirm this in table 5 column 1 in which we include the level of illiteracy interacted with our damage variable. We find the coefficient is negative and significant suggesting that countries with higher level of illiteracy will experience a more adverse affect on output growth as a result of a natural disaster. ${ }^{17}$

\footnotetext{
${ }^{16}$ We also include the direct affect of the institutional/structural factor $(\tau)$ to verify that the identified interaction coefficient is not significant because of the direct correlation of the institutional/structural factor and output growth.

${ }^{17}$ A measure of illiteracy is the only proxy for human capital that is available in the World Development Indicators database in wide enough coverage to maintain our sample size.
} 
In columns 2 and 3 of table 5, we examine whether a higher institutional quality (as measured in the Institutional Country Risk Guides) and higher per capita income levels (in PPP\$) have any impact on the macro-cost of a disaster. We find that indeed both institutional strength and higher per capita incomes are associated with a statistically significant lower macroeconomic cost. The importance of governing institutions can be attributed either to the direct efficiency of the public intervention following the event's onset, or to the indirect impact of an efficient government response in shaping private sector response to the disaster. Our conclusions about income levels corroborate the observations we made in table 4 regarding the difference in output dynamics between developed and developing countries. This result can plausibly be attributed also to the wider diversification observed in higher-income countries and their ability to counter exogenous shocks with counter-cyclical fiscal policy (while fiscal policy in poorer countries is typically pro-cyclical).

We next turn to other structural aspects of the domestic economy and find that a bigger government (measured as government consumption as percent of GDP) and a higher level of exports (as percent of GDP) are both associated with a lower macro-cost of a natural disaster. Both findings are plausible; it is likely that a bigger government will be able to mobilize more resources more rapidly for reconstruction, and that a country that is more open to trade will experience a smaller negative shock to the demand for its products. Countries open to trade may also be more likely recipients of larger international capital inflows to aid in the reconstruction effort. ${ }^{18}$

\footnotetext{
${ }^{18}$ Yang (2006) uses the incidence of hurricanes to examine the consumption smoothing role of international financial flows and finds that foreign aid inflows increase following hurricane events, and, for poorer developing countries, so do remittances. The net aggregate flows to developed countries do not
} 
It has also been hypothesized that geographical location might be a factor in determining the macro-economic secondary costs of disasters. For example, a tropical climate might be conducive to spreading infectious diseases ex post and thus slow down the recovery process; especially when needed resources have to be spent to combat this possibility. We measure the percent of the land area in each country which is in the tropics (between the Tropic of Cancer and the Tropic of Capricorn - 22.5 degrees north and south, respectively). Once this tropics measure is interacted with the property damage variable, we find evidence of the opposite effect - a tropical country is likely to experience higher growth than one which is located outside the tropics following a natural disaster. A potential explanation is the greater ability of agriculture to rebound in tropical climates (where there may well be 3 crop cycles per year).

Finally, since insurance, credit, and financial flows all play a role in disaster recovery, we examine whether financial market conditions matter for the consequences of natural disasters. We start by examining whether the depth of the financial system matters for disaster costs. We proxy the financial system with two measures: the size of the domestic stock market (stock market capitalization - table 6 column 1) and the level of domestic credit (table 6 column 2). We find no evidence that the stock markets are important in insulating economies from the macroeconomic impact of disasters. On the other hand, we do observe that more domestic credit appears to reduce the costs of disasters in terms of foregone output growth.

We next examine whether the degree of openness of the capital account matters for the output dynamics following the disaster. Yang (2006) finds some evidence of disasters but decrease after geological ones. 
capital flight following disaster events - in his paper: hurricanes. We therefore include a variable that measures the degree of de jure openness of the capital account. This measure extends between -2.5 to +2.5 and is described in detail in Chinn and Ito (2006). Maybe not surprisingly in light of Yang's (2006) observations, countries with open capital accounts seem to experience larger drops in their output growth following disasters.

Since this is one of the more surprising results in this paper, we repeat this specification using a different measure of capital account openness (column 4). Our second measure, taken from Edwards (2006), is constructed from different primary sources and measures openness between 0-100. This measure varies less over time than the Chinn-Ito index. Qualitatively, we find the same results for this measure. Though the interaction term, while negative, is no longer statistically distinguishable from the null of no effect.

Finally, we also examine whether the amount of hard-currency reserves held by the authorities matters - reserves can be though of, in this case, as a buffer stock against the capital outflows documented by Yang (2006). We do find that countries with larger stocks of reserves (measured in months of imports) experience lower output declines following the disaster events (table 6 column 5).

\section{Conclusions and caveats}

Our preliminary empirical investigation on the macroeconomic costs of natural disasters, the first such attempt we are aware of, yielded a number of interesting observations. Natural disasters have a statistically observable impact on the 
macroeconomy when these are measured by the amount of property damage incurred. Alternative measures relying on population indicators (number killed and number affected) do not present any statistically identifiable evidence of macroeconomic costs. Furthermore, we found the developing countries face much larger shock to their macroeconomies following a disaster of similar relative magnitude than do developed countries. Similarly, small economies seem to be more vulnerable than larger ones to these same natural adverse events.

We follow up and examine the determinants of these output costs and find that countries with higher literacy rates, better institutions, higher per capita incomes, larger governments and higher degree of openness to trade appear to be better able to withstand the initial disaster shock and prevent it effects spilling deeper into the macroeconomy. Financial conditions also seem to matter. Countries with less open capital accounts, more foreign exchange reserves, and higher levels of domestic credit appear more robust and able to endure natural disasters with less spillover to GDP growth rates.

We also note that we found no evidence to support rejections of a further set of hypotheses. Because of the usual statistical weaknesses of macro panels, we hesitate to conclude that we can confirm any of these hypotheses but rather that, for whatever reason, we have been unable to reject them. We have examined, and found no evidence, that: the relative size of the agricultural or mining/minerals sectors matters; that island economies are more vulnerable to the disasters' indirect costs; that big countries (in land area) are less vulnerable; and that inflation, poverty rates and unemployment increase following disasters. 
We note several important caveats. In this paper, we do not attempt to examine other impacts on the macroeconomy, such as the effects on the government budget, crowding out effects of reconstruction spending or monetized deficits. Identifying these channels and their empirical importance is important for policy-making post disasters. A preliminary exploration of the effect of disasters on investment suggests that investment (measured by gross capital formation) indeed increases immediately following the disaster event but then declines significantly in the following year. A more exhaustive description of these dynamics is left for future research.

Our investigation also did not examine the ex post policy changes that might be triggered by the disaster onset and should therefore be accounted for as part of the true impact of the crisis. Disasters clearly might be catalysts for dramatic policy changes. These disaster-as-a-catalyst for change effects are harder to identify without a more detailed description of the political economy of post disaster recovery and reconstruction. Empirical identification will require a whole new set of identifying assumptions that we find no support for.

The impact of aid on the macroeconomic consequences, on output growth, inflation and employment, are also worth exploring. Even the direction of aid flows following disasters appears to be difficult to pin down as Benson and Clay (2004) argue there are no observable increases in aid inflows (except possibly for very large events), and Yang (2006) and Raddatz (2007) finding the opposite. ${ }^{19}$

Furthermore, our research focused on rapid-onset disasters and, to a large extent, ignored the macro-dynamics of slowly developing natural events such as draughts and famines. The reasons for this omission are two-fold. First, the empirical methodology and

\footnotetext{
${ }^{19}$ Though both Yang (2006) and Raddatz (2007) restrict their results to specific sub-samples.
} 
data necessary to estimate the impact of slowly developing events will have to be quite distinct from the methodology employed here. Second, famines are not entirely (or even largely) naturally occurring events and can often be considered man-made. As such, a different set of exogeneity assumptions will be necessary in order to evaluate their costs.

Our estimates also do not evaluate the long-run impact of natural disasters on growth. While Skidmore and Toya (2002) do provide estimates of the long-run effects, these rely on a cross sectional dataset, in which it is impossible to control for the obvious timeinvariant differences between countries. A possibly more appropriate framework to account for these differences is a methodology similar to that pursued by Barro (1997). This is also left for future research as long-run growth accounting will necessitate a very different framework than that pursued here.

More important than the possible avenues for future research mentioned above is the question of the impact of natural disasters on poverty. A framework to identify the interactions between poverty rates, vulnerability to and impacts of natural disasters and the variations in poverty levels should be developed in cross country settings to complement and enrich the work that has already been done on specific case studies. 


\section{Data Appendix}

\begin{tabular}{lll}
\hline Variable: & Definition: & Source: \\
\hline DDAMG & Damage from disaster (\% of GDP) & EM-DAT and the WDI* \\
DAFFP & Number of people affected by disaster (\% of population) & EM-DAT and the WDI \\
DKILP & Number of people killed by disaster (\% of population) & EM-DAT and the WDI \\
GDPG & GDP growth & WDI \\
\hline RR & Institutional strength & International Country Risk \\
ILIT & Illiteracy (\% of population) & Guides \\
CAPM1 & De jure capital account openness index & WDI \\
CAPM2 & De jure capital account openness index & Chinn and Ito (2006) \\
GDPPC & GDP per capita (in constant 1995 US\$) & Edwards (2006) \\
GCON & Government consumption (\% of GDP) & WDI \\
EXPORT & Exports of goods and services (\% of GDP) & WDI \\
TROPIC & $\%$ of land area in the tropics & WDI \\
SMCG & Stock market capitalization (\% of GDP) & Gallup et al. (1998) \\
FOREX & Foreign exchange reserves (\% of imports) & World Bank's financial dataset \\
DOMCRE & Domestic credit in banking sector (\% of GDP) & WDI \\
\hline GCFGL & Gross capital formation (annual \% growth) & WDI \\
DOMCREL & Domestic credit provided by banking sector (\% of GDP) & WDI \\
CAL & Current account surplus (as \% of GDP) & WDI \\
BUDGETL & Government budget surplus including grants (\% of GDP) & WDI \\
INFLL & Inflation rate (CPI) & WDI \\
IMPGL & Imports (\% of GDP) & WDI \\
FDIL & Foreign direct investment (as \% of GDP) & WDI \\
SSHNG & Financial crisis & Wo05) \\
\hline
\end{tabular}

* World Development Indicators, 2006 CD-ROM. 
Table 1 - Descriptive Statistics for Disaster Variables

\begin{tabular}{lccccc}
\hline Variable & Mean & S.D. & Min. & Max. & Obs. \\
\hline DDAMG & 0.026 & 0.120 & 0.000 & 1.486 & 428 \\
DKILP & 0.085 & 0.654 & 0.000 & 11.047 & 507 \\
DAFFP & 5.438 & 12.686 & 0.000 & 98.767 & 466 \\
\hline
\end{tabular}

Correlation: DKILP-DAFFP: 0.61 DKILP-DDAMG: 0.32 DAFFP-DDAMG: 0.50

For descriptions and sources of the variables, see section 3 in text and the data appendix.

Table 2 - Means/Medians for Disaster Variables by Region (obs.)

\begin{tabular}{lccc}
\hline & DDAMG & DKILP & DAFFP \\
\hline Developed Countries & $0.000 / 0.000$ & $0.000 / 0.000$ & $1.43 / 0.05$ \\
Developing Countries & $(51)$ & $(51)$ & $(50)$ \\
& $0.029 / 0.001$ & $0.094 / 0.001$ & $5.92 / 0.90$ \\
Latin America & $(377)$ & $(456)$ & $(416)$ \\
East Asia & $0.002 / 0.000$ & $0.003 / 0.000$ & $3.77 / 0.62$ \\
& $(83)$ & $(86)$ & $(85)$ \\
South- \& South-East Asia & $0.086 / 0.006$ & $0.379 / 0.006$ & $9.87 / 0.80$ \\
& $(81)$ & $(101)$ & $(69)$ \\
Middle-East \& North-Africa & $0.005 / 0.001$ & $0.014 / 0.001$ & $6.25 / 1.28$ \\
& $(42)$ & $(48)$ & $(48)$ \\
Africa & $0.028 / 0.000$ & $0.011 / 0.001$ & $2.13 / 0.28$ \\
& $(77)$ & $(91)$ & $(90)$ \\
Islands & $0.015 / 0.003$ & $0.014 / 0.001$ & $9.02 / 1.50$ \\
& $(71)$ & $(74)$ & $(70)$ \\
\hline
\end{tabular}

For descriptions and sources of the variables, see section 3 in text and the data appendix. The number of observations is indicated in parentheses. 
Table 3 - Disaster Cost Regressions - Benchmarks

\begin{tabular}{|c|c|c|c|c|c|c|}
\hline \multirow[b]{2}{*}{ Variable } & \multicolumn{3}{|c|}{ Crisis measure in monthly shares } & \multicolumn{3}{|c|}{ Binary crisis } \\
\hline & (1) & $(2)$ & (3) & (4) & (5) & (6) \\
\hline DDAMG & $\begin{array}{r}-86.956 \\
2.054\end{array}$ & & & $\begin{array}{r}-9.564 \\
4.800\end{array}$ & & \\
\hline DAFFP & & $\begin{array}{l}0.477 \\
0.841\end{array}$ & & & $\begin{array}{l}0.314 \\
0.833\end{array}$ & \\
\hline DKILP & & & $\begin{array}{r}743.336 \\
0.775\end{array}$ & & & $\begin{array}{l}0.314 \\
0.833\end{array}$ \\
\hline GDPGL1 & $\begin{array}{r}0.255 \\
10.435\end{array}$ & $\begin{array}{r}0.259 \\
10.594\end{array}$ & $\begin{array}{r}0.259 \\
10.584\end{array}$ & $\begin{array}{l}0.161 \\
5.428\end{array}$ & $\begin{array}{r}0.259 \\
10.613\end{array}$ & $\begin{array}{r}0.259 \\
10.613\end{array}$ \\
\hline Observations & 1574 & 1574 & 1574 & 1574 & 1574 & 1574 \\
\hline Adj-R² & 0.13 & 0.13 & 0.13 & 0.13 & 0.13 & 0.13 \\
\hline F-test & 3.02 & 2.96 & 2.96 & 72.93 & 2.96 & 2.96 \\
\hline
\end{tabular}

Note: The table reports the change in GDP growth from natural disasters and other control variables (dependent variable is GDP growth) in response to a 1 unit change in the variables. Regression is estimated with the Hausman-Taylor (1981) random effects algorithm. The associated $\mathrm{t}$ - statistics are noted below each estimated coefficient. ${ }^{* * *}, * *, *$ indicate the significant level at 1,5 , and 10 percent respectively. 
Table 4 - Disaster Cost - Benchmarks by Size and Income Level

\begin{tabular}{|c|c|c|c|c|c|}
\hline Variable & $\begin{array}{l}\text { (1) } \\
\text { All }\end{array}$ & $\begin{array}{c}(2) \\
\text { OECD }\end{array}$ & $\begin{array}{c}\text { (3) } \\
\text { Developing }\end{array}$ & $\begin{array}{c}(4) \\
\text { Small Econ }\end{array}$ & $\begin{array}{c}(5) \\
\text { Big Econ }\end{array}$ \\
\hline DDAMG & $\begin{array}{r}-82.546 \\
1.927\end{array}$ & $\begin{array}{r}62914 \\
2.539\end{array}$ & $\begin{array}{r}-84.894 \\
1.785\end{array}$ & $\begin{array}{r}-89.579 \\
1.756\end{array}$ & $\begin{array}{r}-44.231 \\
0.142\end{array}$ \\
\hline GDPGL1 & $\begin{array}{l}0.174 \\
5.884\end{array}$ & $\begin{array}{l}0.325 \\
4.267\end{array}$ & $\begin{array}{l}0.181 \\
5.391\end{array}$ & $\begin{array}{l}0.143 \\
3.481\end{array}$ & $\begin{array}{l}0.306 \\
6.735\end{array}$ \\
\hline $\mathrm{RR}$ & $\begin{array}{l}0.043 \\
3.299\end{array}$ & $\begin{array}{l}0.047 \\
1.745\end{array}$ & $\begin{array}{l}0.073 \\
4.174\end{array}$ & $\begin{array}{l}0.072 \\
3.407\end{array}$ & $\begin{array}{l}0.041 \\
2.719\end{array}$ \\
\hline GCFGL & $\begin{array}{r}-0.002 \\
0.274\end{array}$ & $\begin{array}{r}-0.013 \\
0.693\end{array}$ & $\begin{array}{r}-0.003 \\
0.364\end{array}$ & $\begin{array}{r}-0.004 \\
0.480\end{array}$ & $\begin{array}{r}-0.002 \\
0.187\end{array}$ \\
\hline DOMCREL & $\begin{array}{r}-0.009 \\
2.175\end{array}$ & $\begin{array}{r}-0.010 \\
2.373\end{array}$ & $\begin{array}{l}0.001 \\
0.218\end{array}$ & $\begin{array}{l}0.005 \\
0.766\end{array}$ & $\begin{array}{r}-0.018 \\
4.024\end{array}$ \\
\hline CAL & $\begin{array}{l}0.039 \\
2.040\end{array}$ & $\begin{array}{l}0.258 \\
7.164\end{array}$ & $\begin{array}{l}0.037 \\
1.699\end{array}$ & $\begin{array}{l}0.019 \\
0.784\end{array}$ & $\begin{array}{l}0.182 \\
5.351\end{array}$ \\
\hline BUDGETL & $\begin{array}{l}0.000 \\
0.013\end{array}$ & $\begin{array}{r}-0.076 \\
2.539\end{array}$ & $\begin{array}{r}-0.003 \\
0.075\end{array}$ & $\begin{array}{l}0.040 \\
1.002\end{array}$ & $\begin{array}{r}-0.091 \\
2.432\end{array}$ \\
\hline INFLL & $\begin{array}{l}0.000 \\
0.457\end{array}$ & $\begin{array}{l}0.004 \\
0.255\end{array}$ & $\begin{array}{l}0.000 \\
0.500\end{array}$ & $\begin{array}{l}0.000 \\
0.473\end{array}$ & $\begin{array}{l}0.000 \\
0.820\end{array}$ \\
\hline IMPGL & $\begin{array}{l}0.011 \\
1.133\end{array}$ & $\begin{array}{l}0.026 \\
1.041\end{array}$ & $\begin{array}{l}0.008 \\
0.729\end{array}$ & $\begin{array}{l}0.008 \\
0.569\end{array}$ & $\begin{array}{l}0.009 \\
0.683\end{array}$ \\
\hline FDIL & $\begin{array}{l}0.135 \\
3.514\end{array}$ & $\begin{array}{r}-0.038 \\
0.811\end{array}$ & $\begin{array}{l}0.138 \\
3.055\end{array}$ & $\begin{array}{l}0.150 \\
2.984\end{array}$ & $\begin{array}{l}0.092 \\
1.549\end{array}$ \\
\hline SSHNG & $\begin{array}{r}-2.339 \\
2.667 \\
\end{array}$ & $\begin{array}{r}-0.837 \\
2.233 \\
\end{array}$ & $\begin{array}{r}-1.600 \\
2.536 \\
\end{array}$ & $\begin{array}{r}-0.874 \\
0.977 \\
\end{array}$ & $\begin{array}{r}-1.627 \\
3.575 \\
\end{array}$ \\
\hline Observations & 1574 & 374 & 1138 & 745 & 767 \\
\hline Adjusted-R2 & 0.16 & 0.36 & 0.14 & 0.10 & 0.29 \\
\hline F-test & 3.38 & 7.45 & 2.84 & 2.05 & 5.98 \\
\hline
\end{tabular}

Note: The table reports the change in GDP growth from natural disasters and other control variables (dependent variable is GDP growth) in response to a 1 unit change in the variables. Regression is estimated with the Hausman-Taylor (1981) random effects algorithm. The associated $\mathrm{t}$ - statistics are noted below each estimated coefficient. ***,**,* indicate the significant level at 1,5 , and 10 percent respectively. 
Table 5 - The Determinants of Disaster Costs - Real variables

\begin{tabular}{|c|c|c|c|c|c|c|}
\hline Variable $X_{i, t-1}^{1}$ : & Illiteracy & $\begin{array}{c}\text { (2) } \\
\text { Institutional } \\
\text { strength }\end{array}$ & $\begin{array}{c}\text { (3) } \\
\text { GDP per } \\
\text { capita }\end{array}$ & $\begin{array}{c}\text { (4) } \\
\text { Government } \\
\text { consumption }\end{array}$ & Exports & Tropics \\
\hline DDAMG & $\begin{array}{r}28.020 \\
1.228\end{array}$ & $\begin{array}{r}-48.246 \\
1.779\end{array}$ & $\begin{array}{r}-69.527 \\
1.887\end{array}$ & $\begin{array}{r}-149.446 \\
-2.462\end{array}$ & $\begin{array}{r}-337.973 \\
4.519\end{array}$ & $\begin{array}{r}-162.378 \\
2.682\end{array}$ \\
\hline $\mathrm{DDAMG}^{*} \mathrm{X}$ & $\begin{array}{r}-7.645 \\
2.798\end{array}$ & $\begin{array}{l}1.179 \\
1.798\end{array}$ & $\begin{array}{l}1.483 \\
1.795\end{array}$ & $\begin{array}{l}6.381 \\
2.410\end{array}$ & $\begin{array}{l}5.829 \\
4.461\end{array}$ & $\begin{array}{r}81.333 \\
1.881\end{array}$ \\
\hline$X$ & $\begin{array}{l}0.000 \\
2.381\end{array}$ & $\begin{array}{l}0.044 \\
3.405\end{array}$ & $\begin{array}{l}0.000 \\
4.303\end{array}$ & $\begin{array}{r}-0.078 \\
2.698\end{array}$ & $\begin{array}{l}0.031 \\
3.571\end{array}$ & $\begin{array}{r}-0.029 \\
0.080\end{array}$ \\
\hline GDPGL1 & $\begin{array}{l}0.105 \\
2.685\end{array}$ & $\begin{array}{l}0.177 \\
5.964\end{array}$ & $\begin{array}{l}0.164 \\
5.462\end{array}$ & $\begin{array}{l}0.160 \\
5.326\end{array}$ & $\begin{array}{l}0.180 \\
6.103\end{array}$ & $\begin{array}{l}0.182 \\
6.071\end{array}$ \\
\hline RR & $\begin{array}{l}0.079 \\
3.500\end{array}$ & & $\begin{array}{l}0.082 \\
5.176\end{array}$ & $\begin{array}{l}0.064 \\
4.422\end{array}$ & $\begin{array}{l}0.035 \\
2.715\end{array}$ & $\begin{array}{l}0.044 \\
3.436\end{array}$ \\
\hline GCFGL & $\begin{array}{l}0.005 \\
0.540\end{array}$ & $\begin{array}{r}-0.003 \\
0.368\end{array}$ & $\begin{array}{r}-0.002 \\
0.228\end{array}$ & $\begin{array}{r}-0.002 \\
0.326\end{array}$ & $\begin{array}{r}-0.002 \\
0.249\end{array}$ & $\begin{array}{r}-0.002 \\
0.304\end{array}$ \\
\hline DOMCREL & $\begin{array}{r}-0.010 \\
1.233\end{array}$ & $\begin{array}{r}-0.009 \\
2.261\end{array}$ & $\begin{array}{r}-0.001 \\
0.272\end{array}$ & $\begin{array}{r}-0.010 \\
2.177\end{array}$ & $\begin{array}{r}-0.009 \\
2.313\end{array}$ & $\begin{array}{r}-0.009 \\
2.147\end{array}$ \\
\hline CAL & $\begin{array}{l}0.062 \\
2.094\end{array}$ & $\begin{array}{l}0.039 \\
2.016\end{array}$ & $\begin{array}{l}0.053 \\
2.702\end{array}$ & $\begin{array}{l}0.036 \\
1.796\end{array}$ & $\begin{array}{l}0.036 \\
1.897\end{array}$ & $\begin{array}{l}0.040 \\
2.046\end{array}$ \\
\hline BUDGETL & $\begin{array}{r}-0.019 \\
0.479\end{array}$ & $\begin{array}{r}-0.002 \\
0.056\end{array}$ & $\begin{array}{r}-0.010 \\
0.337\end{array}$ & $\begin{array}{r}-0.013 \\
0.433\end{array}$ & $\begin{array}{r}-0.020 \\
0.701\end{array}$ & $\begin{array}{r}-0.003 \\
0.108\end{array}$ \\
\hline INFLL & $\begin{array}{l}0.000 \\
0.483\end{array}$ & $\begin{array}{l}0.000 \\
0.441\end{array}$ & $\begin{array}{l}0.000 \\
0.457\end{array}$ & $\begin{array}{l}0.000 \\
0.391\end{array}$ & $\begin{array}{l}0.000 \\
0.555\end{array}$ & $\begin{array}{l}0.000 \\
0.429\end{array}$ \\
\hline IMPGL & $\begin{array}{l}0.012 \\
1.003\end{array}$ & $\begin{array}{l}0.011 \\
1.162\end{array}$ & $\begin{array}{l}0.011 \\
1.095\end{array}$ & $\begin{array}{l}0.011 \\
1.106\end{array}$ & $\begin{array}{l}0.010 \\
0.997\end{array}$ & $\begin{array}{l}0.010 \\
1.079\end{array}$ \\
\hline FDIL & $\begin{array}{l}0.273 \\
3.967\end{array}$ & $\begin{array}{l}0.135 \\
3.526\end{array}$ & $\begin{array}{l}0.126 \\
3.245\end{array}$ & $\begin{array}{l}0.123 \\
3.132\end{array}$ & $\begin{array}{l}0.099 \\
2.524\end{array}$ & $\begin{array}{l}0.130 \\
3.380\end{array}$ \\
\hline SSHNG & $\begin{array}{l}3.487 \\
2.545 \\
\end{array}$ & $\begin{array}{l}2.452 \\
2.794 \\
\end{array}$ & $\begin{array}{r}-1.459 \\
2.996 \\
\end{array}$ & $\begin{array}{r}-1.564 \\
3.268 \\
\end{array}$ & $\begin{array}{r}-1.591 \\
3.346 \\
\end{array}$ & $\begin{array}{r}-1.411 \\
2.940 \\
\end{array}$ \\
\hline Observations & 980 & 1512 & 1488 & 1496 & 1504 & 1500 \\
\hline Adjusted-R2 & 0.20 & 0.15 & 0.15 & 0.17 & 0.18 & 0.16 \\
\hline F-test & 3.68 & 3.18 & 3.09 & 3.48 & 3.52 & 3.24 \\
\hline
\end{tabular}

Note: The table reports the change in GDP growth from natural disasters and other control variables (dependent variable is GDP growth) in response to a 1 unit change in the variables. Regression is estimated with the Hausman-Taylor (1981) random effects algorithm. The associated t- statistics are noted below each estimated coefficient. ***,**,* indicate the significant level at 1,5 , and 10 percent respectively. 
Table 6 - The Determinants of Disaster Costs - Financial variables

\begin{tabular}{|c|c|c|c|c|c|}
\hline Variable $X_{i, t-1}^{1}$ & $\begin{array}{c}\text { (1) } \\
\text { Stock market } \\
\text { capitalization }\end{array}$ & $\begin{array}{c}(2) \\
\text { Domestic } \\
\text { Credit } \\
\end{array}$ & $\begin{array}{c}\text { (3) } \\
\text { Capital } \\
\text { account } \\
\text { openness I } \\
\end{array}$ & $\begin{array}{c}\text { (4) } \\
\text { Capital } \\
\text { account } \\
\text { openness II }\end{array}$ & $\begin{array}{c}(5) \\
\text { Foreign } \\
\text { Exchange } \\
\text { Reserves } \\
\end{array}$ \\
\hline DDAMG & $\begin{array}{r}-63.983 \\
0.371\end{array}$ & $\begin{array}{r}-216.378 \\
3.370\end{array}$ & $\begin{array}{r}-713.727 \\
7.681\end{array}$ & $\begin{array}{r}-471.740 \\
0.595\end{array}$ & $\begin{array}{r}-219.313 \\
3.384\end{array}$ \\
\hline DDAMG* $X$ & $\begin{array}{r}147.943 \\
0.442\end{array}$ & $\begin{array}{r}228.482 \\
3.309\end{array}$ & $\begin{array}{r}-611.937 \\
7.702\end{array}$ & $\begin{array}{r}-98.289 \\
0.562\end{array}$ & $\begin{array}{r}71.252 \\
3.359\end{array}$ \\
\hline$x$ & $\begin{array}{l}1.002 \\
2.048\end{array}$ & $\begin{array}{r}-0.042 \\
4.466\end{array}$ & $\begin{array}{r}-0.109 \\
0.916\end{array}$ & $\begin{array}{r}-0.013 \\
1.971\end{array}$ & $\begin{array}{l}0.031 \\
0.539\end{array}$ \\
\hline GDPGL1 & $\begin{array}{l}0.130 \\
3.243\end{array}$ & $\begin{array}{l}0.164 \\
5.549\end{array}$ & $\begin{array}{l}0.176 \\
5.297\end{array}$ & $\begin{array}{l}0.198 \\
6.498\end{array}$ & $\begin{array}{l}0.176 \\
5.873\end{array}$ \\
\hline RR & $\begin{array}{l}0.028 \\
1.722\end{array}$ & $\begin{array}{l}0.056 \\
4.077\end{array}$ & $\begin{array}{l}0.040 \\
2.737\end{array}$ & $\begin{array}{l}0.052 \\
3.817\end{array}$ & $\begin{array}{l}0.046 \\
3.345\end{array}$ \\
\hline GCFGL & $\begin{array}{l}0.012 \\
1.129\end{array}$ & $\begin{array}{r}-0.002 \\
0.305\end{array}$ & $\begin{array}{r}-0.011 \\
1.588\end{array}$ & $\begin{array}{r}-0.006 \\
0.829\end{array}$ & $\begin{array}{r}-0.002 \\
0.297\end{array}$ \\
\hline DOMCREL & $\begin{array}{r}-0.022 \\
4.431\end{array}$ & $\begin{array}{l}0.029 \\
2.964\end{array}$ & $\begin{array}{r}-0.005 \\
1.306\end{array}$ & $\begin{array}{r}-0.009 \\
2.301\end{array}$ & $\begin{array}{r}-0.010 \\
2.464\end{array}$ \\
\hline CAL & $\begin{array}{l}0.173 \\
5.924\end{array}$ & $\begin{array}{l}0.032 \\
1.603\end{array}$ & $\begin{array}{l}0.083 \\
4.036\end{array}$ & $\begin{array}{l}0.041 \\
2.077\end{array}$ & $\begin{array}{l}0.033 \\
1.667\end{array}$ \\
\hline BUDGETL & $\begin{array}{r}-0.079 \\
2.204\end{array}$ & $\begin{array}{l}0.011 \\
0.384\end{array}$ & $\begin{array}{r}-0.013 \\
0.445\end{array}$ & $\begin{array}{r}-0.007 \\
0.229\end{array}$ & $\begin{array}{r}-0.007 \\
0.228\end{array}$ \\
\hline INFLL & $\begin{array}{l}0.000 \\
0.151\end{array}$ & $\begin{array}{r}0.000 \\
-0.799\end{array}$ & $\begin{array}{l}0.000 \\
0.392\end{array}$ & $\begin{array}{l}0.000 \\
0.361\end{array}$ & $\begin{array}{l}0.000 \\
0.475\end{array}$ \\
\hline IMPGL & $\begin{array}{l}0.010 \\
0.845\end{array}$ & $\begin{array}{l}0.011 \\
1.157\end{array}$ & $\begin{array}{l}0.020 \\
2.001\end{array}$ & $\begin{array}{l}0.008 \\
0.795\end{array}$ & $\begin{array}{l}0.009 \\
0.943\end{array}$ \\
\hline FDIL & $\begin{array}{l}0.031 \\
0.543\end{array}$ & $\begin{array}{l}0.116 \\
2.983\end{array}$ & $\begin{array}{l}0.246 \\
4.898\end{array}$ & $\begin{array}{l}0.127 \\
3.262\end{array}$ & $\begin{array}{l}0.129 \\
3.360\end{array}$ \\
\hline SSHNG & $\begin{array}{r}-1.783 \\
4.021 \\
\end{array}$ & $\begin{array}{r}-1.563 \\
3.273 \\
\end{array}$ & $\begin{array}{r}-1.657 \\
3.316 \\
\end{array}$ & $\begin{array}{r}-1.433 \\
2.935 \\
\end{array}$ & $\begin{array}{r}-1.648 \\
3.419 \\
\end{array}$ \\
\hline Observations & 867 & 1506 & 1225 & 1462 & 1491 \\
\hline Adjusted-R2 & 0.28 & 0.17 & 0.21 & 0.17 & 0.17 \\
\hline F-test statistic & 5.07 & 3.53 & 4.27 & 3.36 & 3.45 \\
\hline
\end{tabular}




\section{References:}

Albala-Bertrand, J. M., 1993. Political Economy of Large Natural Disasters. Oxford, Clarendon Press.

Baltagi, Badi H., 2005. Econometric Analysis of Panel Data. West Sussex, Wiley \& Sons.

Barro, Robert, 1997. Determinants of Economic Growth: A Cross-Country Empirical Study. Cambridge, MIT Press.

Benson, Charlotte and Edward J. Clay, 2004. Understanding the Economic and Financial Impacts of Natural Disasters. Disaster Risk Management Series No. 4, World Bank.

Chinn, Menzie and Hito Ito. 2006. What Matters for Financial Development? Capital Controls, Institutions, and Interactions. Journal of Development Economics 81(1).

Edwards, Sebastian, 2006. Capital Account Openness and Crises. Journal of International Money and Finance (forthcoming).

Greene, W., 2002. Linear models for panel data. In: LIMDEP Econometric Modelling Guide Volume 1. Plainview, NY: Econometric Software, Inc.

Gallup, John L., Jeffrey D. Sachs, Andrew D. Mellinger, 1998. Geography and Economic Development. NBER Working Paper No. 6849.

Halliday, Timothy, 2006. Migration, Risk and Liquidity Constraints in El Salvador. Economic Development and Cultural Change 54(4), 893 -925.

Hausman, Jerry (2001). Mismeasured Variables in Econometric Analysis: Problems from the Right and Problems from the Left. Journal of Economic Perspectives 15(4), 57-67.

Hausman, Jerry and William Taylor (1981). Panel Data and Unobservable Individual Effects. Econometrica, 49(6), November, 1377-1398.

Holtz-Eakin, Douglas, 2005. Macroeconomic and Budgetary Effects of Hurricanes Katrina and Rita. CBO testimony before the Committee on the Budget of the U.S. House of Representatives. October, $6^{\text {th }}, 2005$.

Honig, Adam, 2005. Do Improvements in Government Quality Necessarily Reduce the Incidence of Sudden Stops? Manuscript.

Horwich, George, 2000. Economic Lessons of the Kobe Earthquake. Economic Development and Cultural Change 521-542.

Hutchison, Michael and Ilan Noy, 2005. How Bad are Twins? Output Costs of Currency and Banking Crises. Journal of Money, Credit and Banking 37(4), 725-752.

Hutchison, Michael and Ilan Noy, 2006. Sudden Stops and the Mexican Wave. Journal of Development Economics 79(1), 225-248. 
IPCC, 2007. Climate Change: The Physical Science Basis. Geneva: Intergovernmental Panel on Climate Change.

IRIN, 2005. Disaster Reduction and the Human Cost of Disaster. Accessed at: http://www.irinnews.org.

Islam, N., 1995. Growth Empirics: A Panel Data Approach. Quarterly Journal of Economics 110, 1127-1170.

Kahn, Matthew E., 2004. The Death Toll from Natural Disasters: The Role of Income, Geography, and Institutions. Review of Economics and Statistics 87(2): 271-284.

Narayan, P. K., 2001. Macroeconomic impact of natural disasters on a small island economy: evidence from a CGE model. Applied Economics Letters 10, 721-723.

Nickell, Stephen, 1981. Biases in Dynamic Models with Fixed Effects. Econometrica 49(6), 1417-1426.

Paxson, Christina H., 1992. Using Weather Variability to Estimate the Response of Savings to Transitory Income in Thailand. American Economic Review 82(1), 15-33.

Raddatz, Claudio, 2007. Are external shocks responsible for the instability of output in lowincome countries? Journal of Development Economics, forthcoming.

Rasmussen, Tobias N., 2004. Macroeconomic Implications of Natural Disasters in the Caribbean. IMF working paper WP/04/224.

Schwartz, Eric, 2006. A needless toll of natural disasters. Boston Globe 3/23/2006.

Selcuk, Faruk and Erinc Yeldan, 2001. On the macroeconomic impact of the August 1999 earthquake in Turkey: a first assessment. Applied Economics Letters 8, 483-488.

Skidmore, Mark and Hideki Toya, 2002. Do natural disasters promote long-run growth? Economic Inquiry 40(4), 664-687.

Skidmore, Mark and Hideki Toya, 2007. Economic development and the impacts of natural disasters. Economic Letters, forthcoming.

Townsend, Robert, 1994. Risk and Insurance in Village India. Econometrica 62(3), 539-591.

Udry, Christopher, 1994. Risk and Saving in Northern Nigeria. American Economic Review 85(5), 1287-1300.

Vos, Rob, Margarita Velasco and Edgar de Labastida, 1999. Economic and Social Effects of El Niño in Ecuador, 1997-1998. Inter-American Development Bank Technical Paper POV-107.

Yang, Dean, 2006. Coping With Disaster: The Impact of Hurricanes on International Financial Flows, 1970-2002. Manuscript. 